\title{
ECONOMIC CONSEQUENCES OF GOING CONCERN AUDIT OPINIONS \\ IN NONPROFIT ORGANIZATIONS
}

\section{Nancy Chun Feng}

Assistant Professor

Accounting Department

Sawyer Business Schools

73 Tremont St, $10^{\text {th }}$ Floor

Boston, MA 02108

cnfeng@suffolk.edu

Acknowledgements This paper is based on my dissertation at Boston University. I am deeply grateful to my dissertation committee chair, Krishnagopal Menon, for his dedicated support and insightful guidance in this research endeavor. I also thank other members of my dissertation committee, Nishi Sinha and Donald Smith, for their valuable advice. I am thankful to Dana Forgione, Elizabeth K. Keating, Richard F. Larkin, Timothy J. Louwers, Suzanne Lowensohn, Stefanie L. Tate, and Michelle Yetman for their helpful suggestions. The paper has also benefited from useful comments from the participants at the 2011 American Accounting Association (AAA) Auditing Section Midyear Meeting, 2011 AAA Government and Nonprofit Midyear Meeting, 2010 AAA Public Interest Section Midyear Meeting, and Boston University Accounting Research Workshop. I also thank Thomas Pollak, the Program Director of National Center for Charitable Statistics (NCCS) in the Urban Institute, for his timely assistance of providing the access to the NCCS data. The author acknowledges the financial support from Boston University School of Management. 


\title{
ECONOMIC CONSEQUENCES OF GOING CONCERN AUDIT OPINIONS IN NONPROFIT ORGANIZATIONS
}

\begin{abstract}
This study examines economic consequences of going concern audit reports (GCARs) in nonprofit organizations (NPOs) using a sample of public charities that received initial GCARs between 1998 and 2003. I find that total contributions decrease after an NPO receives a GCAR, indicating that GCARs lead to adverse economic effects. Further, I find that GCARs are negatively correlated with subsequent government grants, suggesting that the government utilizes a GCAR as a screening criterion in its funding decisions. However, there is no significant correlation between GCARs and subsequent public support. In addition, I find that a GCAR reduces an NPO's debt level in the year after the NPO receives a GCAR, suggesting that creditors react negatively to a GCAR. The findings provide evidence of the information content of GCARs in the nonprofit sector.
\end{abstract}

Keywords: Going concern audit report; nonprofit audit; financial distress; economic consequences of going concern audit opinions.

Data availability: Data used in this study are from public sources. 


\section{ECONOMIC CONSEQUENCES OF GOING CONCERN AUDIT OPINIONS IN NONPROFIT ORGANIZATIONS}

\section{INTRODUCTION}

This study investigates the economic consequences of going concern audit reports (GCARs) in nonprofit organizations (NPOs) in order to evaluate the usefulness of GCARs in the nonprofit setting. A well-established literature has examined and documented investor reactions to GCARs in the for-profit world, but there is no similar evidence for the nonprofit setting. NPOs do not issue stock but rely on donations, government grants, and debt. Knowing whether GCARs play a role in donors' and grantors' contributing decisions and creditors' lending decisions can help policy makers to assess its information content and make policy judgments about auditing in the nonprofit sector.

I expect that a GCAR contains incremental information on an NPO because NPOs generally have few information intermediaries, and auditors possess on-site information unavailable to outsiders and can convey the information via GCARs. A GCAR reflects auditors' pessimistic views of an NPO. Therefore, if a GCAR carries new information about an NPO, the NPO's donations, government grants (grants hereafter), and debt should decline. In contrast, the lack of evidence on adverse economic impacts of GCARs will allow regulators to reallocate limited resources to monitor other aspects of NPOs than GCARs.

My findings show that GCARs negatively impact the level of contributions after NPOs receive their initial GCARs, suggesting that GCARs may cause adverse economic consequences for NPOs. I also find that a GCAR reduces the subsequent grants that an NPO receives, indicating that the government reacts negatively to a GCAR. However, I find no supporting 
evidence that a GCAR reduces public support (as well as direct support and indirect support) that an NPO receives in the post-GCAR year. The level of debt that an NPO receives after the GCAR-year significantly decreases, indicating that creditors may restrict their lending to GCARreceiving NPOs.

The paper focuses on NPOs receiving initial GCARs during Single Audits because initial GCARs contain more incremental information content, if any. It is a particularly difficult decision for auditors to issue a first-time GCAR (Kida 1980; Mutchler 1984). ${ }^{1}$ Auditors will not lift going concern opinions unless the client's conditions significantly improve (Nogler 1995).

This study primarily contributes to the line of research on going concern reports. To my knowledge, this paper offers the first multivariate analysis to document the economic consequences of GCARs in NPOs and evaluate whether GCARs contain incremental information content in the nonprofit world. The findings can be helpful for regulators to assess the value of GCARs in the nonprofit world. The evidence that GCARs have information content may motivate policymakers to enhance the public access to the audit reports of NPOs.

The following section introduces the background. Section 3 reviews the relevant literature and develops hypotheses. Section 4 specifies research methodology and describes the sample selection procedures. Section 5 presents empirical results for main analyses and robustness tests. The final section summarizes the study and provides conclusions.

\footnotetext{
${ }^{1}$ The Single Audit Act of 1984 (OMB 1996, 2007) took effect in 1986 and covers all fifty states, most of the more than 80,000 state and local governmental units, and many NPOs. The Act requires CPA-performed audits on annual financial statements for NPOs that have federal expenditures above $\$ 500,000$ ( $\$ 300,000$ before December 31, 2003).
} 


\section{BACKGROUND: GCARs AND BANKRUPTCIES IN NPOs}

SAS No. 59 (AICPA 1988) provides guidelines for auditors to make appropriate going concern judgments and require auditors to include a going concern explanatory paragraph in an audit report if they have substantial doubts about an entity's ability to operate continuously for one year beyond the auditing date for the financial statements. Single Audit requirements extend well beyond those for Generally Accepted Auditing Standards (GAAS) and Government Auditing Standards (GAGAS) audits. Keating et al. (2005) document that only $136(1.07 \%)$ out of 12,654 audit reports of NPOs under the Single Audit Act contain GCARs between 1997 and 2000. GCARs are issued less frequently in NPOs. ${ }^{2}$

In addition to GCARs, occurrences of bankruptcies are also scarce in NPOs. NPOs only take up one percent of bankruptcy cases even though they constitute thirty percent of all corporations. NPOs cannot be forced to file bankruptcy under federal law (11 U.S.C.A. 303(a)), and creditors must follow state law pertaining to insolvent NPOs (O'Neil and Barnett 1980; Oleck 1992). The lower frequency of bankruptcy in NPOs is perhaps due to high exiting costs (such as attorney fees and efforts to distribute assets) and management's incapability of profiting from liquidation or mergers. When NPOs go bankrupt, the losses to beneficiaries are high because it is difficult to find substitutes for the public goods offered by NPOs.

Despite the rarity of GCARs and bankruptcies in NPOs, the subsequent adverse effects combined with potential reputation losses may motivate NPO managements to make every effort to avoid bankruptcy or GCARs. For instance, in order to continue as a going concern, Kansas City decided to close 29 out of 61 schools in the district at the end of 2010 school year (Hollingswoth 2010) when the district faced potential bankruptcy.

\footnotetext{
${ }^{2}$ Using the Audit Analytics Database, Feng (2010) finds that 16.7\% of 67,041 audit reports of for-profit firms contain GCARs between 2000 and 2003.
} 


\section{HYPOTHESIS DEVELOPMENT}

A GCAR is a negative signal for an NPO. Whether such "bad news" contains incremental information content has been an on-going debate in the for-profit literature. One strand of research reports no negative market reaction to GCARs (Elliott 1982; Dodd et al. 1984; Blay and Geiger 2001; Herbohn et al. 2007) while the other strand of research finds significant negative market reaction to GCARs (Fleak and Wilson 1994; Jones 1996). In a more recent study, Menon and Williams (2010) document a significant negative reaction to the announcement of a GCAR and show that the degree of adverse market reaction increases for firms with a debt covenant restricting the firm from receiving a GCAR and increases with the level of institutional ownership in the firm. Because NPOs do not issue stock, whether donors, grantors, or creditors react to a GCAR in the nonprofit sector is an open empirical question.

\section{The Impact of GCARs on Contributions}

Donors and grantors rely on information about an NPO in order to make contribution decisions. A GCAR becomes a valuable source of information for contributors because it contains auditors' insights about an NPO that auditors have obtained through field examinations. ${ }^{3}$ Moreover, a GCAR reflects an auditor's pessimistic view about the NPO's ability to continue operations, and thus can deter donors from contributing to the NPO. Contributors may donate their resources to another NPO that carries out a similar mission but has no GCARs

\footnotetext{
${ }^{3}$ For instance, only 25 out of 50 states require audited reports from NPOs that have revenues above a minimum threshold. The minimum thresholds differ by state. For example, Connecticut requires audits when gross revenues exceed $\$ 200,000$ while New Hampshire and Massachusetts demand audits when gross revenues are above $\$ 500,000$. The Single Audit Act (OMB 1996) demands audited financial statements only if annual federal expenditures of an NPO are above $\$ 500,000$ (as opposed to $\$ 300,000$ before December 31,2003 ). In addition, there is no quarterly reporting of NPOs, and NPOs can file their financial statements as long as nine months after their fiscal year end.
} 
since the purpose of making contributions is to increase an NPO's service or provision level. ${ }^{4}$ Therefore, the preceding arguments lead to the first hypothesis:

$\mathbf{H}_{\mathbf{1}}$ : The level of contributions decreases after an NPO receives a GCAR.

Contributions of an NPO include public support and government grants. Public support consists of donations directly from individuals and foundations (direct support) and donations from federated fundraising campaigns such as the United Way (indirect support). On one hand, donors may respond negatively to a GCAR of an NPO and discontinue their donations to the GCAR-receiving NPO because they doubt the NPO can continue to carry out its missions. On the other hand, some donors may pitch in to help the organization to survive. Other donors may seek a warm glow (Andreoni 1990; Ribar and Wilhelm 2002) and a GCAR may not affect their donation decisions. In addition, donors (especially individual donors) do not have direct access to an NPO's audit reports unless media exposes the high profile NPOs that have received GCARs or donors take efforts to obtain A-133 audit reports under the Freedom of Information Act (FOIA). Therefore, the net effect of a GCAR on donations is unclear. However, to keep the hypothesis in a consistent format, I use the alternative hypothesis rather than the null form:

$\mathbf{H}_{\mathbf{1 b}}$ : The level of public support decreases after an NPO receives a GCAR.

\footnotetext{
${ }^{4}$ For example, donors offer their support in order to increase the frequency or quality of art exhibits, increase the number of children fed or educated in developing countries, or help low income people to earn more (Vesterlund 2006). Donors are reluctant to make contributions just to pay the debt of a financially distressed college without directly support a mission (O'Neil and Barnett 1980).
} 
In contrast, the government requires audit reports from NPOs that meet either the revenue threshold imposed by state legislations or by the federal expenditure threshold under the Single Audit Act. State auditors themselves often audit NPOs and prepare audit reports. Furthermore, some government agencies use GCARs as one of the screening criteria when they make grant decisions. For example, the New York State Homeless Housing and Assistance Corporation (HHAC), a subsidiary of the New York State Housing Finance Agency (HFA), uses going concern uncertainties as one of the criteria to disqualify an NPO from applying for funding under the Homeless Housing and Assistance Program (HHAP) (The New York State OTDA 2010). Thus, I expect that grantors react negatively to a GCAR.

$\mathbf{H}_{1 \mathbf{c}}$ : The level of government grants decreases after an NPO receives a GCAR.

\section{The Impact of GCARs on Debt}

NPOs borrow debt to obtain funding to purchase equipment and buildings or span the time between expenses and grant receipts (Yetman 2007). The Internal Revenue Service’s Statistics of Income files report that over 60 percent of NPOs owe some form of debt. Debt financing in NPOs is pervasive perhaps due to lack of access to the equity market.

In a recent for-profit study, Menon and Williams (2010) find that a GCAR may be a useful incremental indicator of the firm's difficulties in servicing debt or in raising capital. On the other hand, a GCAR may increase contracting costs and therefore raise the likelihood of bankruptcy, e.g. the "self-fulfilling prophecy" effect of GCARs. Higher contract costs may derive from downgraded credit rating, stricter listing requirements from stock exchanges, and increased difficulties in obtaining credit from bank or other lenders. Some debt may carry restrictive covenants that require the firm to prepare financial statements without a GCAR, and the borrower may have to incur substantial costs to renegotiate the loan, either through higher 
interest rates or other strict debt terms. They contend that investors react more negatively to the announcement of a GCAR when there is a debt covenant that restricts the firm from receiving a GCAR.

For nonprofits, I expect that GCARs adversely affect the level of debt that an NPO receives. A GCAR reflects auditors' pessimistic views about an NPO's financial conditions and thus reduce creditors' confidence in the NPO. A GCAR may result in the breach of loan covenants or lead to higher contracting costs, such as a lower credit rating, the increased cost of existing debt. It is also possible that some debt covenants restrict the NPO from receiving a GCAR. Creditors may become more reluctant to lend to GCAR-receiving NPOs fearing that these NPOs may not be able to repay their loans. However, I recognize that the decline in debt could result from financial distress as well. ${ }^{5}$ Therefore, the second hypothesis is as follows:

$\mathbf{H}_{2}$ : The debt load decreases after an NPO receives a GCAR.

\section{METHODOLOGY}

\section{The Consequence Model for the Impact of GCARs on Contributions}

I follow Petrovits et al. (2011) and use the following Model 1 to test whether GCARs have negative effects on the level of contributions after an NPO receives a GCAR:

$$
\begin{aligned}
\text { LnContributions }_{t}= & \alpha_{0}+\alpha_{1} \text { GCAR }_{t-1}+\alpha_{2} \text { LnPrice }_{t-1}+\alpha_{3} \text { LnProgramRevenue }_{t-1} \\
& +\alpha_{4} \text { LnFundraisingExpense }_{t-1}+\alpha_{5} M W_{t-1}+\alpha_{6} \text { BigN }_{t-1}+\alpha_{7} \text { LnSize }_{t-1} \\
& +\alpha_{8} \text { LnContributions }_{t-1}+\alpha_{9} \text { IMR }+\tau_{1-6} \sum_{\mathrm{i}=1}{ }^{6} \text { NTEE }+\psi_{1-6} \sum_{\mathrm{i}=1}{ }^{6} \text { Year }+\varepsilon
\end{aligned}
$$

\footnotetext{
${ }^{5}$ For example, in the footnotes to the 1999 financial statements of Mon Yough Community Services, Inc. in McKeesport, Pennsylvania, the entity disclosed that "these negative trends have continued resulting in requirements by its primary lender to prohibit further borrowings from its line of credit and for management to submit a corrective action plan prior to any consideration of potential future financing arrangements."
} 
The dependent variable is LnContributions. To examine the impact of GCARs on public support and government grants, I replace the dependent variable with LnPublicSupport and LnGovernmentGrants to re-estimate Model 1. The variable of interest is GCAR. I expect a negative coefficient for GCAR (i.e., $\alpha_{1}<0$ ), implying that receiving a GCAR reduces the total contributions that an NPO receives in the post-GCAR year. Yet there may be unobservable differences between the NPOs that receive a GCAR and the NPOs without a GCAR that auditors take into their going concern considerations but are omitted in the model. To mitigate the selection bias, I apply the Heckman's (1979) two-stage estimation method. In the first stage, I use the GCAR likelihood probit model developed by Feng (2010) to calculate the Inverse Mills ratio. ${ }^{6}$ In the second-stage model, I include the Inverse Mills ratio (IMR) as a bias correction term to control for the selection bias. Following Petrovits et al (2011), I include the price of donating (LnPrice), program service revenues (LnProgramRevenue), fundraising expenses (LnFundraisingExpense), and material weakness $(M W)$. The natural log form of the variables in the model helps to mitigate the heterogeneity among NPOs.

The price of donating measures how many dollars of after-tax income that a donor must give up in order to provide one additional dollar to an NPO's final output. Weisbrod and Dominguez (1986) and Petrovits et al. (2011) consider price a function of the program service ratio and the tax benefit of donating. ${ }^{7}$ Both studies find a significant negative relationship

\footnotetext{
${ }^{6}$ Feng (2010) develops the GCAR likelihood model (see Appendix for variable definitions):

GCAR $=\quad \beta_{0}+\beta_{1}$ LowOPRSVR $+\beta_{2}$ GRTLoss $+\beta_{3}$ PSREVLoss $+\beta_{4}$ LDTA + $\beta_{5} V u l+\beta_{6} C R+\beta_{7} L O S S 2+\beta_{8} M W+\beta_{9} M N C+\beta_{10}$ FREXPR + $\beta_{11}$ LSize $+\beta_{12}$ GRTSIG $+\beta_{13}$ PSREVSIG $+\beta_{14}$ GRTSIG*GRTLoss + $\beta_{15}$ PSREVSIG*PSREVLoss $+\varphi_{1-6} \sum_{\mathrm{i}=1}{ }^{6}$ NTEE $+\delta_{1-6} \sum_{\mathrm{j}=1}{ }^{6}$ Year $+\varepsilon$
}

7 Weisbrod and Dominguez (1986) define price as follows: Price $=\frac{(1-T)}{1-(A+F)}$ 
between price and the level of contributions. I follow the same approach to calculate the price of donating.

$$
\text { PRICE }_{t-1}=\frac{1-T_{t-1}}{1-\frac{\text { FUNDRAISINGExpenses }_{t-1}+\text { ADMINExpenses }_{t-1}}{\text { TotalCONTRIB }_{t-1}}}
$$

The variable LnProgramRevenue controls for the crowding-in effects (Khanna and Sandler 2000; Okten and Weisbrod 2000), and thus I expect a positive coefficient for this variable. The variable LnFundraisingExpense controls for the organization's efforts to lower information asymmetry (Weisbrod and Dominguez 1986) and is expected to have a positive impact on contributions. Petrovits et al. (2011) document that internal control deficiencies negatively affect contributions, thus I expect a negative correlation between material weakness (a stronger form of internal control than reportable contributions) and subsequent contributions. Kitching (2009) finds that NPOs with a Big 5 auditor receive more contributions than NPOs with a smaller auditor. Thus, I include an indicator variable $B i g N$ to proxy for auditor reputation and expect a positive coefficient for LnSize. To control for the impact of organization reputation on contributions, I use total assets (LnSize) rather than organization age because two variables are highly correlated and the size variable controls for both the size effect and the reputation effect

Where $T$ is the marginal income tax rate of an organization. $(A+F)$ is the percentage of an NPO's revenues that are spent on fundraising and administration. Later in their paper, they use the following operational formula to calculate price:

$$
\text { Price }=\frac{1-T}{1-F}=\frac{1-T}{1-\frac{F U N D}{D O N}}
$$

Where FUND is the fundraising expenditures and $D O N$ is the "Contributions, gifts and grants" received by an NPO in the previous period. They set the percentage of revenue devoted to administration at zero because they think that satisfactory data on these expenses are unavailable. Since the donor's tax rate is uniform across all NPOs, the price reduces to the ratio of total expenses to program services expenses. 
(Tinkelman 2004). I also include the lagged contributions to control for other organization characteristics. Model 1 also controls for the industry and fixed year effects.

Contributions do not instantaneously reflect the impact of influencing factors, because contributors cannot retroactively make their contribution decisions. Therefore, I expect that contributions are sensitive to the indicators of organizational performance in the preceding accounting period. In the models with LnPublicSupport and LnGovernmentGrants, I use the corresponding lagged public support or government grants as control variables respectively.

\section{The Consequence Models for the Impact of GCARs on Debt}

Wedig et al. $(1988,1996)$ have studied tax-exempt debt and the capital structure of nonprofit organizations for nonprofit hospitals, but not for general NPOs. To test the effects of GCARs on the level of debt, I use Model 2:

$$
\begin{aligned}
\text { LnLTD }_{t}= & \eta_{0}+\eta_{1} \text { GCAR }_{t-1}+\eta_{2} \text { LnRevenue }_{t-1}+\eta_{3} \text { LnLowOperatingReserveRatio } t-1 \\
& +\eta_{4} M W_{t-1}+\eta_{5} \text { BigN }_{t-1}+\eta_{6} \text { LnSize }_{t-1}+\eta_{7} \text { LnLTD }_{t-1}+\eta_{8} I M R \\
& +\tau_{1-6} \sum_{i=1}{ }^{6} \text { NTEE }+\psi_{1-6} \sum_{i=1}{ }^{6} \text { Year }+\varepsilon
\end{aligned}
$$

$G C A R$ is the variable of interest. Per $H_{2}$, I expect the coefficient $\eta_{1}$ to be negative because creditors may become reluctant to make loan to the NPO fearing that the NPO is unable to repay the loan. When an NPO has more revenues, there is less need for the NPO to borrow debt, so I anticipate a negative coefficient for LnRevenue. If an NPO has low operating reserves, the need to borrow is high. However, creditors may deny an NPO with low operating reserves because they suspect the NPO cannot service the loan. Thus, the coefficient $\eta_{4}$ is expected to be negative. I further expect the size of an NPO to be positively correlated with its debt because large NPOs generally need more funding to support their operations and have better credentials to borrow 
from creditors. I expect that material weakness reduces an NPO's ability to borrow more since creditors may be concerned about the integrity of the organization. BigN auditors typically have better relationships with banks, thus I expect $\eta_{5}$ to be positive. The prior year debt is included to control for other organization-specific characteristics. The industry and year controls are also incorporated in Model 2.

\section{Sample Selection}

I use the Federal Audit Clearinghouse (FAC) database and the National Center of Charity Statistics (NCCS) database in this study. The FAC database contains the Single Audit data for NPOs, including auditors' opinions on the financial reporting. The NCCS database contains NPOs' financial data that are obtained from Form 990s. The nonprofit literature has been using the NCCS data in lieu of data from financial statements because two sets of data are highly correlated and it is difficult to obtain NPOs' financial statements (Krishnan et al. 2006; Keating et al. 2008; Kitching 2009; Petrovits et al. 2011).

\section{Going Concern Sample}

The going concern sample consists of NPOs that received an initial GCAR between 1998 and 2003 in the FAC Database. I select this study period because Digitized Files in the NCCS Database contain necessary financial data on public charities from 1998 to $2003 .{ }^{8}$ Table 1 Panel A shows the sample selection process. The final sample includes 405 NPOs that received their initial GCARs within the study period.

\section{[PLEASE SEE TABLE 1]}

\footnotetext{
${ }^{8}$ According to the NCCS staff, they cannot compile another set of Digitized Files with more recent data due to a lack of funding. Therefore, the study period of the main analyses extends only until 2003.
} 


\section{Control Sample}

Chen and Church (1992) and Mutchler $(1984,1985)$ have noted that in the for-profit setting, auditors first identify problem NPOs and then decide whether to issue GCARs. To examine whether their selection criteria apply to NPOs, I have collected 172 going concern audit reports out of the sample through the FOIA procedure. I rank the reasons for issuing GCARs by the frequency that auditors have cited each justification in GCARs, and the top three reasons are: (1) negative net assets or insolvency (i.e., total liabilities are greater than total assets); (2) losses; or (3) negative working capital. ${ }^{9}$ Therefore, control group includes NPOs that meet at least one of the three criteria. For each going concern NPO, I find a peer NPO that has the closest total assets within the same NTEE and fiscal year combination. Thus, the control group consists of 405 NPOs through the aforementioned matching process.

In order to mitigate the impact of outliers, I winsorize main financial data at the $1 \%$ and 99\% levels after selecting the control group.

\section{RESULTS}

\section{Univariate Analyses}

\section{The Yearly and Sector Distributions of the Sample}

Table 1 Panel B displays the frequency of NPOs that received their first-time GCARs between 1998 and 2003 and shows an even distribution across the study period. Panel C shows that observations are more concentrated in the Human Services (47\%) and Health sectors (29\%). The Education (10\%) and Public and Societal Benefits (10\%) sectors are the next two largest

\footnotetext{
${ }^{9}$ Out of 172 collected GCARs, 90 GCARs were issued because of an NPO's net asset deficiency, 83 GCARs were issued because of an NPO's significant or recurring losses, and 57 GCARs were issued because of an NPO's working capital deficiencies.
} 
ones. The Arts, Culture, and Humanities (1\%) and Other sectors (2\%) are two smallest groups. The sector distribution is generally consistent with that of the NPO population.

\section{The Going Concern (GC) Sample and its Control Group}

Table 2 provides descriptive statistics of the first-time GC sample and the control sample in the year when an NPO received its initial GCAR. Panel A compares the balance sheet items between the two groups. Paired t-tests for the differences in means reveal that, on average, going concern NPOs have higher long-term debt $(t=2.70, p$-value at the $1 \%$ level $)$ and total liabilities ( $t=2.34, p$-value at the $5 \%$ level), and lower unrestricted net assets ( $t=-2.48, p$-value at the $1 \%$ level) and total net assets (or fund balances) ( $t=-2.36, p$-value at the $5 \%$ level) than peer NPOs. In addition, the GC sample borrows more debt and has fewer unrestricted net assets to draw upon for operational activities. Panel A suggests that the GC sample may have higher financing risk than its peer group.

\section{[PLEASE SEE TABLE 2]}

Panel B compares revenues and expenses between the GC sample and the control group. The paired $t$-test statistics suggest that in general, the GC sample receives less direct ( $t=-1.90, p$ value at the $10 \%$ level) and indirect public support ( $t=-2.97, p$-value at the $1 \%$ level). More importantly, the GC sample has a larger deficit ( $t=-2.35, p$-value at the $5 \%$ level) than its peer group, indicating that GCAR-receiving NPOs are more financially distressed than their peers.

\section{The GC Sample in the Post-GCAR Periods}

I also obtain the descriptive statistics of these NPOs in the year after the GCAR issuance in order to investigate conditions of the GCAR-receiving NPOs after they received their firsttime GCARs. Table 3 Panel A displays descriptive statistics of the balance sheet items. The 
mean total assets of these 305 NPOs in the post-GCAR year are higher than the sample mean. NPOs in the post-GCAR period also have higher means in current assets, current liabilities, longterm debt, total liabilities, temporarily restricted and permanently restricted net assets than those in the GCAR-year. Panel B shows that the means of program service revenues ( $\$ 9.5$ million) and total revenues ( $\$ 12.5$ million) of 305 NPOs are higher than the sample means in the GCAR-year. The evidence in Table 3 suggests that larger NPOs are perhaps more likely to survive after receiving GCARs.

\section{[PLEASE SEE TABLE 3]}

To examine the survivorship of the GCAR-receiving NPOs, I checked the frequency of GCAR-receiving NPOs in the NCCS Core Files from 1999 to $2006 .{ }^{10}$ In addition, the NCCS Data Guide (NCCS 2006) defines active NPOs as those organizations that provide services. Using this definition, I calculated the frequency of NPOs with zero program service revenues in the NCCS Core Files. Both frequencies are presented in Table 4. Panel A lists the number of NPOs that remained in the NCCS Core Files after NPOs received their GCARs. Panel B shows the number of NPOs that had zero program service revenues. The declining counts of existing NPOs in the Core Files from 1999 to 2006 suggest that more and more GCAR-receiving NPOs cease to operate. The counts of the NPOs with zero program service revenues do not show a declining trend, perhaps because some NPOs may no longer exist.

[PLEASE SEE TABLE 4]

\footnotetext{
${ }^{10}$ I use the Core Files instead of the Business Master Files (BMFs) because the NCCS Guide to Using NCCS data (NCCS Data Guide hereafter; NCCS 2006) indicates that the BMFs may contain inactive or defunct organizations due to data errors in the IRS files. The Core Files contain more accurate data sets since the NCCS cleansed the IRS data.
} 


\section{Pearson Correlation Matrix}

The Pearson correlation between major variables is shown in Table 5. As expected, the correlations between a GCAR and total contributions, public support and indirect support are negative, but insignificant. The correlation between a GCAR and the debt level in the postGCAR year is unexpectedly positive. However, without controlling for other variables in a multivariate context, I cannot draw definite inferences from the correlation analysis. I also calculate the variance inflation factors using the ordinary least-squares for each regression models and find that multicollinearity is not a significant issue.

\section{[PLEASE SEE TABLE 5]}

\section{Multivariate Analyses}

Table 6 presents second-stage regression estimates for the impacts of GCARs on total contributions. The variable GCAR has a negative coefficient (-0.588), suggesting that all else equal, having a GCAR is associated with 58.8 percent fewer contributions on average in the post-GCAR year. This evidence is consistent with the first hypothesis that a GCAR has a detrimental impact on subsequent contributions and indicates that GCARs of NPOs contain substantial incremental information content. As expected, the fundraising expenses are significantly positively correlated with total contributions, indicating that fundraising expenses help to increase contributors' confidence in the organizations. The contributions of the GCAR

year are significantly positively correlated with the contributions of the post-GCAR year. The coefficients of variables LnPrice, LnProgramRevenue, $M W$, LnSize and BigN all have the expected sign, but are insignificant. The coefficient of the Inverse Mills ratio $(I M R)$ is not significant, suggesting that sample selection bias is not an issue and the inferences drawn from the results are valid. 


\section{[PLEASE SEE TABLE 6]}

I also estimate the impact of GCARs on the components of total contributions: public support and government grants. Table 7 presents the regression results for the impact of GCARs on public support and its components (i.e. direct support and indirect support) respectively. Surprisingly, the variable $G C A R$ is negative, but insignificant across three regressions, suggesting that GCARs do not adversely affect public support. Some donors perhaps donate to seek a warm glow and thus do not care about GCARs. Yet other donors may be so keen to support the organization's mission that they would like to pitch in to help the NPO to survive when a GCAR is issued. The above mentioned circumstances can potentially mitigate the negative impact of GCARs on public support.

\section{[PLEASE SEE TABLE 7]}

In contrast, Table 8 reports that the coefficient on GCAR (-0.396) is significantly negative ( $p=0.024$ ), suggesting that having a GCAR reduces subsequent government grants. The variable LnGovernmentGrants $(0.970)$ has a significantly positive coefficient, suggesting a high correlation with the government grants in the GCAR-year. The sign of the coefficient on LnSize is positive, as expected, but the signs of the coefficients on LnPrice, LnProgramRevenue, $M W$, and $B i g N$ are opposite to the expectations, which I do not have explanations. Nevertheless, the coefficients on LnPrice, LnProgramRevenue, $M W$, BigN, and LnSize are insignificant.

\section{[PLEASE SEE TABLE 8]}

Finally, Table 9 presents the results for the second-stage regression estimates of Model 2. As predicted, the coefficient on GCAR is significantly negative, suggesting that an NPO with a GCAR receives 52.6 percent less debt than an NPO without a GCAR in the post-GCAR year. 
The total revenues are negatively (coefficient=-0.073) correlated with an NPO's debt, indicating that having more revenues may reduce the need for an NPO to borrow more debt. The coefficient of the variable LowOperatingReserveRatio is positive, but insignificant. The signs of the coefficients of $M W$ and $B i g N$ are opposite to the expectation, but insignificant. LnSize also has an insignificant coefficient. The coefficient estimates on the Inverse Mills ratio (IMR) are significant, suggesting that selection bias may exist. However, the incorporation of the Inverse Mills ratio $(I M R)$ in the second-stage models mitigates selection bias.

\section{[PLEASE SEE TABLE 9]}

\section{Robustness Tests}

\section{Alternative Variables and Measures}

I use the variable Price instead of the natural log of Price to re-estimate Model 1 since several prior studies have used this format (Kitching 2009; Petrovits et al. 2011). The regression results and the inferences drawn here are similar to those in the main analyses. I also replace the variable $M W$ with reportable conditions $(R C)$, another form of internal control deficiencies, in the estimations. The untabulated regression results of these robustness tests are qualitatively same to the main results except for the estimates for the impacts of a GCAR on total contributions and indirect support. The robustness test results show that a GCAR $(-0.355)$ does not significantly reduce total contributions ( $p=0.127$ ), unlike the corresponding regression in the main analyses. In contrast, the robustness test shows that a GCAR (-0.709) significantly decreases the indirect support $(p=0.085)$ in the post-GCAR year, while the corresponding regression in the main analyses shows no significant correlation between a GCAR and the 
subsequent indirect support. Nevertheless, the overall robustness tests suggest that the main results and the inferences drawn from the main analyses are generally robust.

\section{CONCLUSIONS}

The purpose of this study is to investigate the economic consequences of GCARs in NPOs, i.e., the impacts of GCARs on total contributions and debt. I examine economic consequences of GCARs on total contributions (as well as public support and government grants) and debt that an NPO receives after the entity gets its initial GCAR. The results show that the level of total contributions decreases after NPOs receive their initial GCARs. Subsequent government grants that the GCAR-recipients receive also decline, indicating that government agencies react negatively to GCARs. However, I find no evidence that a GCAR affects public support that an NPO receives. Furthermore, I find that having a GCAR reduces the subsequent debt that an NPO borrows from creditors, suggesting the adverse impact of a GCAR on debt.

The major contributions of the paper are: First, this study offers the first multivariate investigation on economic consequences of GCARs in the nonprofit setting. Second, the study documents the adverse effects GCARs have on contributions, government grants, and debt. Examining the economic consequences of GCARs helps us to understand the value of GCARs. Adverse economic impacts will motivate NPOs (particularly financially distressed ones) to improve financial performance, strengthen internal control, and comply with laws, regulations and contract agreements in order to mitigate the likelihood of getting a GCAR. Moreover, the

findings help regulators to assess the impacts that GCARs have on nonprofit organizations and can facilitate their policy making in the nonprofit audits. 


\section{REFERENCES}

American Institute of Certified Public Accountants (AICPA). 1988. Statement on Auditing Standards No. 59: The Auditor's Consideration of an Entity's Ability to Continue as a Going Concern. New York, NY: American Institute of Certified Public Accountants.

Andreoni, J. 1990. Impure altruism and donations to public goods: A theory of warm-glow giving. The Economic Journal 100 (401): 464-477.

Blay, A. and Geiger. M. A. 2001. Market expectations for first-time going-concern recipients. Journal of Accounting, Auditing \& Finance. Vol. 16 (3): 209-226.

Chen, K. C. W., and B. K. Church. 1992. Default on debt obligations and the issuance of going concern opinions. Auditing: A Journal of Practice \& Theory 20 (1): 30-49.

Dodd, P., N. Dopuch, R. Holthausen and R. Leftwish. 1984. Qualified audit opinions and stock prices. Journal of Accounting and Economics 6 (1): 3-38.

Elliott, J. A. 1982. "Subject to" audit opinions and abnormal security returns - outcomes and ambiguities. Journal of Accounting Research 20 (2): 617-638.

Feng, N. C. 2010. Determinants of going-concern audit opinions in nonprofit organizations. Working paper. Providence College.

Fleak, S. K. and E. R. Wilson. 1994. The incremental information content of the going-concern audit opinion. Journal of Accounting, Auditing and Finance 9 (4): 149-166.

Heckman, J. 1979. Sample selection bias as a specification error. Econometrica 47 (1): 153-161.

Herbohn, K., V. Ragunathan, and R. Garsden. 2007. The horse has bolted: revisiting the market reaction to going concern modifications of audit reports. Accounting and Finance 47 (3): 473-493.

Hollingswoth, H. 2010. Mass school closures approved in Kansas City, Mo. http://www.freerepublic.com/focus/news/2468581/posts

Jones, F. L. 1996. The information content of the auditor's going concern evaluation. Journal of Accounting and Public Policy 15 (1): 1-27.

Khanna, J. and T. Sandler. 2000. Partners in giving: the crowding-in effect of UK government grants. European Economic Review 44(8): 1543-1556.

Keating, E. K., T. P. Gordon, M. Fischer, and J. Greenlee. 2005. The Single Audit Act: How compliant are nonprofit organizations? Journal of Public Budgeting, Accounting \& Financial Management 17 (3): 285-309. 
, L. M. Parsons, and A. A. Roberts. 2008. Misreporting fundraising: how do nonprofit organizations account for telemarketing campaigns? The Accounting Review 83 (2): 417-446.

Kida, T. 1980. An investigation into auditor's continuity and related qualification judgments. Journal of Accounting Research 18 (3): 506-523.

Kitching, K. 2009. Audit value and charitable organizations. Journal of Accounting and Public Policy 28 (6): 510-524.

Krishnan, R., M. H. Yetman, and R. J. Yetman. 2006. Expense Misreporting in Nonprofit Organizations. The Accounting Review 81 (2): 399-420.

Menon, K., and D. D. Williams. 2010. Investor reaction to going concern audit reports. The Accounting Review, 85 (6): 2075-2105.

Mutchler, J. F. 1984. Auditors' perceptions of the going concern opinion decision. Auditing: A Journal of Practice \& Theory 3 (2): 17-30. 1985. A multivariate analysis of the auditor's going concern opinion decision. Journal of Accounting Research 23 (2): 668-682.

National Center for Charitable Statistics (NCCS). 2006. Guide to use NCCS data. Washington D.C., The Urban Institute.

Nogler, G. 1995. The resolution of auditor going concern opinions. Auditing: A Journal of Practice \& Theory 14 (2): 54-73.

Office of Management and Budget (OMB). 1996. Circular No. A-133: Audits of States, Local Governments, and Non-Profit Organizations. Washington, DC. .2007. Circular No. A-133: Audits of States, Local Governments, and Non-Profit Organizations. Revised to show changes published in the Federal Register June 27, 2003. Washington, DC.

Okten, C. and B. Weisbrod. 2000. Determinants of donations in private nonprofit markets. Journal of Public Economics 75(2): 255-272.

Oleck, H. L. 1992. Nonprofit corporations, organizations and associations. Englewood Cliffs, N.J.: Prentice-Hall.

O’Neil, J. P., and Barnett, S. 1980. College and corporate change: Merger, bankruptcy, and closure. Princeton, NJ: Conference-University Press.

Petrovits, C., C. Shakespeare, and A. Shih. 2011. The causes and consequences of internal control problems in nonprofit organizations. The Accounting Review 86 (1): 325-357. 
Ribar, D., and M. Wilhelm. 2002. Altruistic and joy-of-giving motivations in charitable behavior. The Journal of Political Economy 110 (2): 425-457.

Thorton, J. P. and W. H. Belski. 2009. Financial reporting quality and price competition among nonprofit firms. Applied Economics. iFirst: 1-15.

Tinkelman, D. 2004. Using nonprofit organization-level financial data to infer managers' fund-raising strategies. Journal of Public Economics 88: 2181-2192.

Vesterlund, L. 2006. Why do people give? The nonprofit sector: a research handbook, edited by Powell W. W. and Steinberg, R. New Haven, CT: Yale University Press.

Weisbrod, B. A., and N. D. Dominguez. 1986. Demand for collective goods in private markets: Can fundraising expenditures help overcome free-rider behavior? Journal of Public Economics 30: 83-96.

Yetman, R. 2007. Borrowing and debt. Financing nonprofits: putting theory into practice, edited by Young D. R., 243-268. Lanham, MD: AltaMira Press. 


\section{APPENDIX Variable Definitions (Alphabetical Order)}
$\operatorname{BigN}$
$=$ An indicator variable set to 1 if an NPO hires one of the top audit firms, and 0 otherwise
$C R$
$=$ Current ratio, i.e., Total current assets $(=$ Cash (Part IV, line 45$)+$ Savings and temporary cash investments (Part IV, line 46) + Accounts receivable (Part IV, line 47) + Pledges receivables (Part IV, line 48) + Grants Receivables (Part IV, line 49) + Inventories for sale or use (Part IV, line 52) + Prepaid expenses and deferred charges (Part IV, line 53))/Total current liabilities (=Total liabilities (Part IV, line 66) - Loans from officers, directors, trustees, and key employees (Part IV, line 63) - Tax-exempt bond liabilities (Part IV, line 64) - Mortgages and other notes payables (Part IV, line 64))
FREXPR = Fundraising expense ratio, i.e., Fundraising expenses (Part I, line 15)/Total contributions (Part I, line 1d)
GCAR = An indicator variable set to 1 if a GCAR is issued to an auditee, and 0 otherwise
GRTLoss = An indicator variable set to 1 if government grants (Part I, line 1c) that an NPO receives decrease in the year when it receives GCAR, and 0 otherwise
GRTSIG = An indicator variable set to 1 if the percentage of grants (Part I, line 1c) in an NPO's total revenues (Part I, line 12) is above the thresholds, and 0 otherwise

GRTSIG*GRTLoss=The interaction term between GRTSIG and GRTLoss.

IMR = The Inverse Mills ratio computed using the GCAR likelihood model as the first-stage model, following Heckman (1979) two-stage estimation process

LDTA = Total long-term debt/Total assets, i.e., [(Tax-exempt bonds (Part IV, line 64a) + Mortgages and other notes payable (Part IV, line 64b))]/Total assets (Part IV, line 59)

LnContributions $_{t}=$ The natural log of total contributions (Part I, line 1d) of year $t$

LnDirectSupport $t_{t}=$ The natural $\log$ of direct public support (Part I, line 1a) of year $t$

LnFundraisingExpenses

$=$ The natural log of fundraising expenses (Part I, line 15) 


\section{LnGovernmentGrants}

$=$ The natural log of government grants (Part I, line 1c) of year $t$.

$\operatorname{LnLTD}_{t} \quad=$ The natural log of Total long-term debt (=Tax-exempt bonds (Part IV, line 64a) + Mortgages and other notes payable (Part IV, line 64b))

LnIndirectSupport $t_{t}=$ The natural $\log$ of indirect public support (Part I, line 1b) of year $t$

LnPrice $t-1_{2}=$ The natural log of the price of donating of year $t-1$

LnProgramRevenue $t-1$

$=$ The natural log of Program service revenues (Part I, line 2) of year $t-1$

LnPublicSupport $_{t}=$ The natural log of Public Support, i.e. Direct public Support (Part I, line 1a) + Indirect public Support (Part I, line 1b) of year $t$

LOSS2 = An indicator variable set to 1 if an NPO has incurred loss for two consecutive years, i.e., for the year prior to a GCAR and the GCAR year

LowOperatingReserveRatio (LowOPRSVR in the first stage model (Feng 2010))

$=$ An indicator variable set to 1 if the operating reserve ratio is below $25 \%$, 0 otherwise. The operating reserve ratio is calculated as total operating reserves/total operating expenses, i.e., [Unrestricted net assets (Part IV, line 67) - fixed assets net of debt (=Land, buildings, and equipment (Part IV, line 57) - Mortgages and other notes payable (Part IV, line 64b)]/[Total functional expenses (Part II, line 44 in Column A) Depreciation, depletion, etc. (Part II, line 42 Column A)]

LnSize (LSize in the first stage model (Feng (2010))

$=$ The natural log of a client's total assets (Part IV, line 59)

MNC = An indicator variable set to 1 if an auditor reports material noncompliance on a Single Audit report, and 0 otherwise

$M W=$ An indicator variable set to 1 if an auditor reports material weaknesses on a Single Audit report, and 0 otherwise

NTEE $\quad=$ National Taxonomy of Exempt Entity Code

Price $_{t-1}=$ The price of donation at year t-1. I follow a calculation method similar to Petrovits et al. (2009) to calculate the price of donation. Price of donating $=$ Total contributions $($ Part I, line $1 \mathrm{~d}) /[($ Total contributions (Fundraising expenses (Part I, line 15) + Administrative Expenses (Part I, line 14)] 
PSREVLoss = An indicator variable set to 1 if program service revenues (Part I, line 2) that an NPO receives decrease in the year when it receives GCAR, and 0 otherwise

PSREVSIG = An indicator variable set to 1 if the percentage of program service revenues (Part I, line 13) in an NPO's total revenues (Part I, line 12) is above the thresholds, and 0 otherwise

PSREVSIG*PSREVLosS

=The interaction term between PSREVSIG and PSREVLoss.

$R C=$ An indicator variable set to 1 if an auditor reports reportable conditions on a Single Audit report, and 0 otherwise

Vul $=$ An indicator variable set to 1 if the calculated probability of financial vulnerability is greater than $10 \%$ as suggested by Greenlee and Trussel (2000), and 0 otherwise

Year $=$ Fiscal year 


\section{Table 1 Sample Selection}

\section{Panel A: Sample Selection}

Number of first-time going concern NPOs in 1998-2003 $\quad 1,106$

- NPOs that are not in the NCCS Digitized Files 439

- NPOs without necessary financial information 203

- NPOs received a GCAR due to dissolution or mergers 19

- NPOs without going concern opinions in GCARs ${ }^{11} \quad 40$

Number of first-time going concern NPOs in the final sample $\quad \underline{\underline{405}}$

\section{Panel B: First-time GCARs By Year}

\begin{tabular}{|c|c|c|}
\hline \multirow{2}{*}{ Year } & \multicolumn{2}{|c|}{ First-time GCARs } \\
\cline { 2 - 3 } & Frequency & $\%$ \\
\hline 1998 & 68 & $16.79 \%$ \\
1999 & 64 & $15.80 \%$ \\
2000 & 60 & $14.81 \%$ \\
2001 & 67 & $16.54 \%$ \\
2002 & 75 & $18.52 \%$ \\
2003 & 71 & $17.53 \%$ \\
\hline TOTAL & 405 & $100.0 \%$ \\
\hline
\end{tabular}

Panel C: Sector Distribution for the First-time GC Sample

\begin{tabular}{lrr}
\hline \multirow{2}{*}{$\begin{array}{c}\text { Sector } \\
\text { (by NTEE) }\end{array}$} & \multicolumn{2}{c}{ First-time } \\
\cline { 2 - 3 } GC Sample \\
\hline \hline Arts, Culture, and Humanities & 5 & $1.23 \%$ \\
Education & 42 & $10.37 \%$ \\
Health & 120 & $29.63 \%$ \\
Human Services & 191 & $47.16 \%$ \\
Public and Societal Benefits & 40 & $9.88 \%$ \\
Other & 7 & $1.73 \%$ \\
& & \\
Total & 405 & $100 \%$ \\
\hline \hline
\end{tabular}

\footnotetext{
${ }^{11}$ I hand collected 172 GCARs via the FOIA procedure and find that 40 GCARs do not contain going concern audit opinions. I do not have a complete set of GCARs for the sample because of the difficulties in the FOIA collection process.
} 
Table 2

Descriptive Statistics: The First-time GC Sample and Its Peer Group (in thousands)

\begin{tabular}{|c|c|c|c|c|c|c|c|c|c|c|c|c|}
\hline & \multicolumn{6}{|c|}{ GC Sample } & \multicolumn{5}{|c|}{ Peer Group } & \multirow[b]{2}{*}{$\begin{array}{c}\text { Paired } \\
\text { t-test } \\
\text { t-value }\end{array}$} \\
\hline & $\mathbf{N}$ & Mean & $\begin{array}{l}\text { Standard } \\
\text { Deviation } \\
\end{array}$ & $\begin{array}{c}\text { Lower } \\
\text { Quartile } \\
\end{array}$ & Median & $\begin{array}{c}\text { Upper } \\
\text { Quartile } \\
\end{array}$ & Mean & $\begin{array}{l}\text { Standard } \\
\text { Deviation }\end{array}$ & $\begin{array}{c}\text { Lower } \\
\text { Quartile }\end{array}$ & Median & $\begin{array}{c}\text { Upper } \\
\text { Quartile } \\
\end{array}$ & \\
\hline \multicolumn{13}{|l|}{ Panel A Balance Sheet } \\
\hline Current Assets & 405 & $2,065.81$ & $7,047.27$ & 117.02 & 359.53 & 972.61 & $2,150.30$ & $7,808.87$ & 99.96 & 383.93 & $1,308.37$ & -0.45 \\
\hline Total Assets & 405 & $7,681.88$ & $25,157.03$ & 396.56 & $1,357.25$ & $3,979.09$ & $7,683.44$ & $25,320.12$ & 397.49 & $1,357.73$ & $3,977.24$ & -0.05 \\
\hline Current Liabilities & 405 & $3,506.36$ & $14,524.12$ & 124.86 & 378.13 & $1,210.69$ & $3,148.70$ & $19,662.06$ & 66.97 & 229.78 & $1,087.15$ & 0.52 \\
\hline Total Liabilities & 405 & $7,094.44$ & $25,649.01$ & 254.88 & 934.00 & $3,259.79$ & $5,097.88$ & $25,017.61$ & 143.51 & 599.06 & $2,009.67$ & $2.34^{\mathrm{b}}$ \\
\hline Operating Reserves & 405 & $-1,131.69$ & $7,517.48$ & -317.81 & -28.08 & 74.84 & -383.75 & $12,830.19$ & -35.94 & 53.23 & 328.26 & -1.05 \\
\hline Unrestricted Net Assets & 405 & -138.64 & $8,209.19$ & -229.54 & 0.00 & 238.67 & $1,895.12$ & $11,430.56$ & 0.00 & 172.32 & $1,369.99$ & $-2.48^{\mathrm{a}}$ \\
\hline Temporarily Restricted Net Assets & 405 & 417.72 & $2,057.52$ & 0.00 & 0.00 & 121.82 & 353.60 & $1,535.03$ & 0.00 & 0.00 & 92.28 & 0.54 \\
\hline Permanently Restricted Net Assets & 405 & 278.71 & $1,292.03$ & 0.00 & 0.00 & 0.00 & 280.32 & $1,505.76$ & 0.00 & 0.00 & 0.00 & -0.02 \\
\hline Total Net Assets or Fund Balances & 405 & 587.43 & $8,829.23$ & -150.19 & 62.08 & 626.55 & $2,585.63$ & $12,602.06$ & 36.06 & 289.94 & $1,587.30$ & $-2.36^{\mathrm{b}}$ \\
\hline \multicolumn{13}{|l|}{ Panel B Revenues and Expenses } \\
\hline Total Contributions & 405 & $2,562.46$ & $5,295.69$ & 389.77 & 887.16 & $2,326.58$ & $3,096.90$ & $7,734.94$ & 443.24 & $1,044.04$ & $2,719.02$ & -1.22 \\
\hline Direct Public Support & 405 & 369.12 & $1,395.84$ & 0.00 & 14.91 & 184.30 & 825.17 & $4,840.63$ & 0.00 & 16.68 & 150.96 & $-1.90^{\mathrm{c}}$ \\
\hline Indirect Public Support & 405 & 33.05 & 138.36 & 0.00 & 0.00 & 0.00 & 87.66 & 346.56 & 0.00 & 0.00 & 15.64 & $-2.97^{\mathrm{a}}$ \\
\hline Government Grants & 405 & $2,160.29$ & $5,049.69$ & 128.63 & 684.81 & $1,861.97$ & $2,198.00$ & $5,437.40$ & 177.41 & 714.43 & $1,998.91$ & -0.10 \\
\hline Program Service Revenues & 405 & $7,988.78$ & $35,924.80$ & 0.19 & 297.25 & $2,075.86$ & $6,823.67$ & $41,378.06$ & 6.81 & 124.42 & $1,039.44$ & 0.82 \\
\hline Membership Dues and Assessments & 405 & 25.74 & 454.82 & 0.00 & 0.00 & 0.00 & 90.19 & 825.30 & 0.00 & 0.00 & 0.00 & -1.37 \\
\hline Other Investment Income & 405 & 132.91 & 963.74 & 0.00 & 0.92 & 18.06 & 109.19 & 560.59 & 0.00 & 1.32 & 20.60 & 0.49 \\
\hline Interest Income & 405 & 38.31 & 217.30 & 0.00 & 0.64 & 5.15 & 29.11 & 132.72 & 0.00 & 1.32 & 10.00 & 0.80 \\
\hline Total Revenues & 405 & $10,961.78$ & $38,492.88$ & 818.86 & $1,876.76$ & $5,447.51$ & $10,291.81$ & $43,013.46$ & 731.23 & $1,739.60$ & $5,740.66$ & 0.48 \\
\hline Program Service Expenses & 405 & $9,803.87$ & $35,561.62$ & 746.27 & $1,670.88$ & $4,959.24$ & $9,150.17$ & $40,360.96$ & 641.04 & $1,597.88$ & $5,166.72$ & 0.51 \\
\hline Fundraising Expenses & 405 & 49.35 & 339.43 & 0.00 & 0.00 & 0.00 & 130.57 & 944.12 & 0.00 & 0.00 & 8.99 & -1.66 \\
\hline Management and General Expenses & 405 & $1,795.25$ & $6,436.85$ & 90.28 & 266.70 & 860.58 & $1,288.19$ & $5,396.81$ & 59.89 & 200.38 & 628.06 & 1.83 \\
\hline Total Expenses & 405 & $11,666.20$ & $41,145.86$ & 876.78 & $1,980.57$ & $5,949.76$ & $10,571.84$ & $45,225.22$ & 765.05 & $1,850.49$ & $5,889.94$ & 0.75 \\
\hline Excess (or deficit) for the year & 405 & -704.22 & $3,787.82$ & -335.98 & -82.58 & -2.51 & -277.38 & $3,065.92$ & -135.66 & -23.79 & -2.71 & $-2.35^{\mathrm{b}}$ \\
\hline
\end{tabular}


Table 3

Descriptive Statistics: The First-time Going Concern Sample in the Post-GCAR Year (in thousands)

\begin{tabular}{|c|c|c|c|c|c|c|c|c|}
\hline & $\mathbf{N}$ & Mean & $\begin{array}{l}\text { Standard } \\
\text { Deviation }\end{array}$ & P1 & $\begin{array}{r}\text { Lower } \\
\text { Quartile } \\
\end{array}$ & Median & $\begin{array}{r}\text { Upper } \\
\text { Quartile } \\
\end{array}$ & P99 \\
\hline \multicolumn{9}{|l|}{ Panel A Balance Sheet } \\
\hline Current Assets & 305 & $2,492.79$ & $9,642.54$ & 0.35 & 95.31 & 404.95 & 937.78 & $46,234.41$ \\
\hline Total Assets & 305 & $8,394.14$ & $26,763.06$ & 8.34 & 305.16 & $1,233.84$ & $3,923.51$ & $164,812.70$ \\
\hline Current Liabilities & 305 & $4,614.30$ & $19,241.88$ & 0.00 & 94.82 & 400.52 & $1,115.89$ & $115,374.47$ \\
\hline Long-term Debt & 305 & $3,694.71$ & $17,933.09$ & 0.00 & 0.00 & 163.53 & $1,713.29$ & $80,660.00$ \\
\hline Total Liabilities & 305 & $8,314.46$ & $30,332.20$ & 0.00 & 244.17 & 918.99 & $3,637.99$ & $155,533.83$ \\
\hline Unrestricted Net Assets & 305 & -696.91 & $10,155.96$ & $-16,372.45$ & -278.81 & 0.00 & 219.58 & $10,631.95$ \\
\hline Temporarily Restricted Net Assets & 305 & 482.20 & $2,440.04$ & 0.00 & 0.00 & 0.00 & 90.89 & $8,476.40$ \\
\hline Permanently Restricted Net Assets & 305 & 337.54 & $1,478.82$ & 0.00 & 0.00 & 0.00 & 0.00 & $9,508.53$ \\
\hline Total Net Assets or Fund Balances & 305 & 79.75 & $10,653.41$ & $-15,427.17$ & -191.44 & 45.80 & 551.89 & $25,262.80$ \\
\hline \multicolumn{9}{|l|}{ Panel B Revenues and Expenses } \\
\hline Total Contributions & 305 & $2,523.04$ & $5,190.51$ & 0.00 & 254.04 & 932.77 & $2,371.09$ & $19,735.66$ \\
\hline Direct Public Support & 305 & 429.21 & $1,399.89$ & 0.00 & 0.00 & 21.00 & 191.17 & $5,692.89$ \\
\hline Indirect Public Support & 305 & 59.43 & 360.13 & 0.00 & 0.00 & 0.00 & 0.00 & $1,337.97$ \\
\hline Government Grants & 305 & $2,034.41$ & $4,816.30$ & 0.00 & 64.17 & 652.09 & $1,683.26$ & $17,516.61$ \\
\hline Program Service Revenues & 305 & $9,464.20$ & $39,964.48$ & 0.00 & 0.00 & 337.38 & $2,618.98$ & $242,481.99$ \\
\hline Membership Dues and Assessments & 305 & 3.59 & 30.59 & 0.00 & 0.00 & 0.00 & 0.00 & 84.53 \\
\hline Other Investment Income & 305 & 194.49 & $1,230.95$ & 0.00 & 0.00 & 1.73 & 22.00 & $3,837.37$ \\
\hline Interest Income & 305 & 352.95 & $1,324.42$ & 0.00 & 0.00 & 7.77 & 134.29 & $7,588.10$ \\
\hline Total Revenues & 305 & $12,463.53$ & $43,064.01$ & 55.28 & 810.63 & $2,062.41$ & $5,663.74$ & $252,813.23$ \\
\hline Program Service Expenses & 305 & $10,928.34$ & $39,353.39$ & 49.10 & 644.40 & $1,774.14$ & $4,931.91$ & $231,370.48$ \\
\hline Fundraising Expenses & 305 & 32.48 & 111.30 & 0.00 & 0.00 & 0.00 & 0.00 & 546.38 \\
\hline Management and General Expenses & 305 & $2,199.65$ & $8,532.37$ & 0.00 & 88.64 & 296.35 & 930.79 & $45,368.72$ \\
\hline Total Expenses & 305 & $13,171.15$ & $46,111.94$ & 78.57 & 798.52 & $2,039.97$ & $6,049.36$ & $264,580.01$ \\
\hline Excess (or deficit) for the year & 305 & -707.53 & $4,036.35$ & $-19,708.70$ & -136.86 & -12.90 & 82.60 & $2,258.79$ \\
\hline
\end{tabular}


Table 4

Frequency of GCAR-receiving NPOs that remain in the NCCS Core Files or have Zero Program Service Revenues: $1999-2006^{12}$

\section{Panel A Frequency of GCAR-receiving NPOs that remain in the NCCS Core Files}

\begin{tabular}{|c|c|c|c|c|c|c|c|c|}
\hline $\begin{array}{l}\text { Year when an NPO } \\
\text { received a GCAR }\end{array}$ & 1999 & 2000 & 2001 & 2002 & 2003 & 2004 & 2005 & 2006 \\
\hline GCAR1998 & 53 & 45 & 43 & 41 & 41 & 40 & 38 & 37 \\
\hline GCAR1999 & & 45 & 50 & 39 & 37 & 33 & 37 & 37 \\
\hline GCAR2000 & & & 44 & 40 & 36 & 36 & 35 & 31 \\
\hline GCAR2001 & & & & 52 & 49 & 46 & 42 & 42 \\
\hline GCAR2002 & & & & & 58 & 50 & 44 & 45 \\
\hline GCAR2003 & & & & & & 54 & 53 & 52 \\
\hline
\end{tabular}

\footnotetext{
${ }^{12}$ As suggested by the NCCS Guide to Using NCCS Data, I combine all the core files from 1999 and 2006 to get the complete list of NPO filings for each fiscal year. I retain only the most recent filing for each fiscal year by removing older filings for the same fiscal year. I use the CORE files to generate this table because according to the NCCS, BMF Files may contain inactive or defunct organizations due the data errors in the IRS files. The CORE files include a more accurate data set after the NCCS cleaned up the IRS Return Transaction Files (RTF). The RTF files contain data on all 501(c)(3) organizations that were required to file a Form 990 or Form 990-EZ. The NCCS also excludes foreign organizations or those generally considered as part of the government.
} 
Table 4 (Continued)

Frequency of GCAR-receiving NPOs that remain in the NCCS Core Files or have Zero Program Service Revenues: 1999-2006

Panel B Frequency of GCAR-receiving NPOs that have Zero Program Service Revenues

\begin{tabular}{lrrrrrrrr}
\hline \hline $\begin{array}{l}\text { Year when an NPO } \\
\text { received a GCAR }\end{array}$ & 1999 & 2000 & 2001 & 2002 & 2003 & 2004 & 2005 & 2006 \\
\hline GCAR1998 & 15 & 12 & 11 & 9 & 9 & 8 & 10 & 8 \\
GCAR1999 & & 6 & 8 & 4 & 3 & 3 & 3 & 5 \\
GCAR2000 & & 7 & 7 & 6 & 7 & 7 & 8 \\
GCAR2001 & & & 12 & 11 & 10 & 9 & 8 \\
GCAR2002 & & & & & 13 & 12 & 6 & 5 \\
GCAR2003 & & & & & & 9 & 10 & 8 \\
\hline \hline
\end{tabular}


Table 5 Pearson Correlation Matrix $(N=810)$

\begin{tabular}{|c|c|c|c|c|c|c|c|}
\hline \multirow{3}{*}{ LnContributions } & \multicolumn{3}{|c|}{ LnGovernment } & \multicolumn{4}{|c|}{ LnIndirect } \\
\hline & LnContributions & Grants & LnPublicSupport & LnDirectSupport & Support & LnLTD & GCAR \\
\hline & 1.000 & $0.900^{\mathrm{a}}$ & $0.491^{\mathrm{a}}$ & $0.470^{\mathrm{a}}$ & $0.273^{\mathrm{a}}$ & 0.048 & -0.054 \\
\hline LnGovernmentGrants & & 1.000 & $0.096^{\mathrm{c}}$ & 0.084 & $0.169^{\mathrm{b}}$ & 0.023 & 0.043 \\
\hline LnPublicSupport & & & 1.000 & $0.935^{\mathrm{a}}$ & $0.628^{\mathrm{a}}$ & $0.247^{\mathrm{a}}$ & -0.019 \\
\hline LnDirectSupport & & & & 1.000 & $0.186^{\mathrm{b}}$ & $0.259^{\mathrm{a}}$ & 0.012 \\
\hline LnIndirectSupport & & & & & 1.000 & 0.227 & -0.094 \\
\hline LnLTD & & & & & & 1.000 & $0.121^{\mathrm{b}}$ \\
\hline \multirow[t]{3}{*}{ GCAR } & & & & & & & 1.000 \\
\hline & & & & LnProgram & undraising & & \\
\hline & MW & LnPrice & LnRevenue & Revenue & Expenses & LnSize & BigN \\
\hline LnContributions & 0.013 & -0.027 & $0.559^{\mathrm{a}}$ & $0.139^{\mathrm{a}}$ & $0.226^{\mathrm{a}}$ & $0.236^{\mathrm{a}}$ & $0.160^{\mathrm{a}}$ \\
\hline LnGovernmentGrants & 0.030 & $-0.142^{\mathrm{a}}$ & $0.622^{\mathrm{a}}$ & $0.227^{\mathrm{a}}$ & $0.088^{\mathrm{b}}$ & $0.235^{\mathrm{a}}$ & $0.142^{\mathrm{a}}$ \\
\hline LnPublicSupport & -0.030 & $0.207^{\mathrm{a}}$ & $0.422^{\mathrm{a}}$ & $0.251^{\mathrm{a}}$ & $0.448^{\mathrm{a}}$ & $0.413^{\mathrm{a}}$ & $0.264^{\mathrm{a}}$ \\
\hline LnDirectSupport & -0.004 & $0.228^{\mathrm{a}}$ & $0.409^{\mathrm{a}}$ & $0.240^{\mathrm{a}}$ & $0.464^{\mathrm{a}}$ & $0.411^{\mathrm{a}}$ & $0.268^{\mathrm{a}}$ \\
\hline LnIndirectSupport & -0.117 & -0.095 & $0.287^{\mathrm{a}}$ & $0.173^{\mathrm{b}}$ & 0.126 & $0.355^{\mathrm{a}}$ & $0.227^{\mathrm{a}}$ \\
\hline LnLTD & -0.055 & 0.091 & $0.396^{\mathrm{a}}$ & $0.532^{\mathrm{a}}$ & $0.109^{\mathrm{b}}$ & $0.746^{\mathrm{a}}$ & $0.328^{\mathrm{a}}$ \\
\hline GCAR & $0.318^{\mathrm{a}}$ & $0.102^{\mathrm{a}}$ & 0.042 & $0.106^{\mathrm{a}}$ & $-0.058^{\mathrm{c}}$ & 0.000 & 0.025 \\
\hline MW & 1.000 & 0.020 & -0.019 & $-0.066^{\mathrm{c}}$ & -0.047 & -0.009 & $-0.074^{\mathrm{b}}$ \\
\hline LnPrice & & 1.000 & $0.117^{\mathrm{a}}$ & $0.343^{\mathrm{a}}$ & $0.119^{\mathrm{a}}$ & $0.174^{\mathrm{a}}$ & 0.006 \\
\hline LnRevenue & & & 1.000 & $0.734^{\mathrm{a}}$ & $0.222^{\mathrm{a}}$ & $0.670^{\mathrm{a}}$ & $0.293^{\mathrm{a}}$ \\
\hline LnProgramRevenue & & & & 1.000 & $0.082^{\mathrm{b}}$ & $0.668^{\mathrm{a}}$ & $0.238^{\mathrm{a}}$ \\
\hline LnFundraisingExpenses & & & & & 1.000 & $0.191^{\mathrm{a}}$ & $0.126^{\mathrm{a}}$ \\
\hline LnSize & & & & & & 1.000 & $0.338^{\mathrm{a}}$ \\
\hline BigN & & & & & & & 1.000 \\
\hline
\end{tabular}

Note: $a, b, c$ denotes significance at the $0.01,0.05$, and 0.10 levels, respectively. See Appendix for variable definitions. 
Table 6

Second-stage Regression Results

The Impact of GCARs on Total Contributions Using Model 1

Model 1: LnContributions $_{t}=\alpha_{0}+\alpha_{1}$ GCAR $_{t-1}+\alpha_{2}$ LnPrice $_{t-1}+\alpha_{3}$ LnProgramRevenue $_{t-1}$

$+\alpha_{4}$ LnFundraisingExpense $_{t-1}+\alpha_{5} M W_{t-1}+\alpha_{6}$ BigN $_{t-1}$

$+\alpha_{7}$ LnSize $_{t-1}+\alpha_{8}$ LnContributions $_{t-1}+\alpha_{9} I M R$

$+\tau_{1-6} \sum_{i=1}^{6} \mathrm{NTEE}+\psi_{1-6} \sum_{i=1}^{6}$ Year $+\varepsilon$

\begin{tabular}{|l|c|r|r|}
\hline $\mathrm{n}=331$ & $\begin{array}{c}\text { Expected } \\
\text { Sign }\end{array}$ & Coefficient & t-Statistics \\
\hline Intercept & N/A & $1.789^{\mathrm{a}}$ & 2.94 \\
GCAR & - & $-0.588^{\mathrm{c}}$ & -1.86 \\
LnPrice & - & -0.031 & -0.38 \\
LnProgramRevenue & + & -0.030 & -1.13 \\
LnFundraisingExpense & + & $0.015^{\mathrm{c}}$ & 1.78 \\
MW & - & 0.232 & 1.26 \\
BigN & + & 0.296 & 1.11 \\
LnSize & + & -0.001 & -0.04 \\
LnContributions & + & $0.923^{\mathrm{a}}$ & 27.82 \\
IMR & N/A & 0.307 & 1.55 \\
$R^{2}$ (adjusted) & & & $81.20 \%$ \\
F Value & & & 80.17 \\
& & & $(\mathrm{p}<0.001)$ \\
\hline
\end{tabular}

Note: a, b, c denotes significance at the $0.01,0.05$, and 0.10 levels, respectively, all twotailed. See Appendix for variable definitions. 
Table 7

Second-stage Regression Results

The Impact of GCARs on Public Support

Model 1: LnPublicSupport $t_{t}=\alpha_{0}+\alpha_{1}$ GCAR $_{t-1}+\alpha_{2}$ LnPrice $_{t-1}+\alpha_{3}$ LnProgramRevenue $_{t-1}+\alpha_{4}$ LnFundraisingExpense $_{t-1}$

$+\alpha_{5} M W_{t-1}+\alpha_{6}$ BigN $_{t-1}+\alpha_{7}$ LnSize $_{t-1}+\alpha_{8}$ LnPublicSupport $_{t-1}+\alpha_{9} I M R$

$+\tau_{1-6} \sum_{i=1}{ }^{6}$ NTEE $+\psi_{1-6} \sum_{i=1}^{6}$ Year $+\varepsilon$

\begin{tabular}{|c|c|c|c|c|c|c|c|}
\hline & \multirow[t]{2}{*}{$\begin{array}{l}\text { Expected } \\
\text { Sign }\end{array}$} & \multicolumn{2}{|c|}{$\begin{array}{l}\text { Public Support } \\
\text { As the Dependant Variable } \\
(n=231)\end{array}$} & \multicolumn{2}{|c|}{$\begin{array}{c}\text { Direct Support } \\
\text { As the Dependant Variable } \\
(n=217)\end{array}$} & \multicolumn{2}{|c|}{$\begin{array}{c}\text { Indirect Support } \\
\text { As the Dependant Variable } \\
(n=91)\end{array}$} \\
\hline & & Coefficient & t-Statistics & Coefficient & t-Statistics & Coefficient & t-Statistics \\
\hline Intercept & $\mathrm{N} / \mathrm{A}$ & -0.625 & -0.49 & -0.683 & -0.46 & 1.718 & 1.68 \\
\hline$G C A R$ & - & -0.166 & -0.24 & -0.013 & -0.02 & -0.787 & 0.15 \\
\hline LnPrice & - & 0.280 & 1.62 & 0.299 & 1.49 & 0.232 & 1.13 \\
\hline LnProgramRevenue & + & -0.115 & -2.04 & $-0.120^{c}$ & -1.78 & -0.082 & -1.53 \\
\hline LnFundraisingExpens & + & $0.052^{\mathrm{a}}$ & 3.00 & $0.061^{\mathrm{a}}$ & 3.06 & -0.012 & -0.98 \\
\hline$M W$ & - & 0.096 & 0.24 & 0.200 & 0.42 & 0.068 & 0.19 \\
\hline$B i g N$ & + & 0.525 & 1.37 & 0.665 & 1.47 & $0.518^{\mathrm{c}}$ & 1.65 \\
\hline LnSize & + & $0.175^{\mathrm{b}}$ & 2.15 & $0.228^{\mathrm{b}}$ & 2.37 & 0.026 & 0.32 \\
\hline LnPublicSupport & + & $0.759^{\mathrm{a}}$ & 14.96 & & & & \\
\hline LnDirectSupport & + & & & $0.714^{\mathrm{a}}$ & 12.25 & & \\
\hline LnIndirectSupport & + & & & & & $0.887^{\mathrm{a}}$ & 18.22 \\
\hline$I M R$ & N/A & -0.072 & -0.17 & -0.115 & -0.22 & 0.466 & 1.32 \\
\hline$R^{L}$ (adjusted) & & & $71.38 \%$ & & $68.12 \%$ & & $84.29 \%$ \\
\hline$F$ Value & & & $\begin{array}{r}32.87 \\
(p<0.001)\end{array}$ & & $\begin{array}{r}26.64 \\
(p<0.001)\end{array}$ & & $\begin{array}{r}29.40 \\
(p<0.001)\end{array}$ \\
\hline
\end{tabular}

Notes: $\mathrm{a}, \mathrm{b}, \mathrm{c}$ denotes significance at the $0.01,0.05$, and 0.10 levels, respectively, all two-tailed. See Appendix for variable definitions. 
Table 8

Second-stage Regression Results The Impact of GCARs on Government Grants

Model 1: LnGovernmentGrants $s_{t}=\alpha_{0}+\alpha_{1}$ GCAR $_{t-1}+\alpha_{2}$ LnPrice $_{t-1}$

$+\alpha_{3}$ LnProgramRevenue $_{t-1}+\alpha_{4}$ LnFundraisingExpense $_{t-1}$

$+\alpha_{5} M W_{t-1}+\alpha_{6}$ BigN $_{t-1}+\alpha_{7}$ LnSize $_{t-1}$

$+\alpha_{8}$ LnContributions $_{t-1}+\alpha_{9}$ IMR

$+\tau_{1-6} \sum_{i=1}^{6} N T E E+\psi_{1-6} \sum_{i=1}^{6}$ Year $+\varepsilon$

\begin{tabular}{|l|c|r|r|}
\hline $\mathrm{n}=314$ & $\begin{array}{c}\text { Expected } \\
\text { Sign }\end{array}$ & Coefficient & t-Statistics \\
\hline Intercept & N/A & 0.457 & 1.35 \\
GCAR & - & $-0.396^{\mathrm{b}}$ & -2.27 \\
LnPrice & - & 0.037 & 0.75 \\
LnProgramRevenue & + & -0.006 & -0.38 \\
LnFundraisingExpense & + & -0.000 & -0.15 \\
MW & - & 0.048 & 0.46 \\
BigN & + & -0.004 & -0.04 \\
LnSize & + & 0.023 & 1.13 \\
LnGovernmentGrants & + & $0.970^{\mathrm{a}}$ & 54.20 \\
IMR & N/A & 0.149 & 1.36 \\
$R^{2}$ (adjusted) & & & $93.29 \%$ \\
F Value & & & $(\mathrm{p}<0.001)$ \\
\end{tabular}

Note: $a, b$, c denotes significance at the $0.01,0.05$, and 0.10 levels, respectively, all twotailed. See Appendix for variable definitions. 


\section{Table 9}

\section{Second-stage Regression Results}

The Impact of GCARs on Debt

Model 2: $\operatorname{LnLTD}_{t}=\eta_{0}+\eta_{1} G_{C A R_{t-1}}+\eta_{2}$ LnRevenue $_{t-1}+\eta_{3}$ Low OperatingReserveRatio $_{t-1}$

$$
+\eta_{4} M W_{t-1}+\eta_{5} \text { BigN }_{t-1}+\eta_{6} \text { LnSize }_{t-1}+\eta_{7} L_{L} L T D_{t-1}+\eta_{8} I M R
$$

$$
+\tau_{1-6} \sum_{i=1}^{6} N T E E+\psi_{1-6} \sum_{i=1}^{6} \text { Year }+\varepsilon
$$

\begin{tabular}{|l|c|r|r|}
\hline $\mathrm{n}=333$ & $\begin{array}{c}\text { Expected } \\
\text { Sign }\end{array}$ & Coefficient & t-Statistics \\
\hline Intercept & N/A & 0.610 & 1.32 \\
GCAR & - & $-0.526^{\mathrm{b}}$ & -1.95 \\
LnRevenue & - & $-0.073^{\mathrm{b}}$ & -2.17 \\
LowOperatingReserveRatio & - & 0.149 & 1.64 \\
MW & - & 0.099 & 0.71 \\
BigN & + & -0.064 & -0.54 \\
LnSize & + & 0.066 & 1.23 \\
LnLTD & + & $0.959^{\mathrm{a}}$ & 26.29 \\
IMR & N/A & $0.344^{\mathrm{b}}$ & 2.11 \\
$R^{2}$ (adjusted) & & & $91.65 \%$ \\
F Value & & & 215.37 \\
& & & $(\mathrm{p}<0.001)$ \\
\hline
\end{tabular}

Note: $a, b, c$ denotes significance at the $0.01,0.05$, and 0.10 levels, respectively, all two-tailed. See Appendix for variable definitions. 